\title{
Nigeria's quest for alternative clean energy development: A cobweb of opportunities, pitfalls and multiple dilemmas
}

\author{
Agaptus Nwozor ${ }^{\mathrm{a}, \mathrm{c}, *}$, Segun Oshewolo ${ }^{\mathrm{a}}$, Gbenga Owoeye ${ }^{\mathrm{a}}$, Onjefu Okidu ${ }^{\mathrm{b}}$ \\ ${ }^{a}$ Department of Political Science and International Relations, Landmark University, Omu Aran, Kwara State, Nigeria \\ ${ }^{\mathrm{b}}$ Mass Communication Programme, Landmark University, Omu Aran, Kwara State, Nigeria \\ ${ }^{\mathrm{c}}$ Landmark University SDG 7 (Affordable and Clean Energy Research Group), Nigeria
}

\section{A R T I C L E I N F O}

\section{Keywords:}

Alternative clean energy

Energy mix

Renewable energy

Energy transition targets

Nigeria

\begin{abstract}
A B S T R A C T
Nigeria has made pledges at various international fora to mainstream renewable energy in its energy mix. In keeping with these pledges, the country's domain for alternative clean energy development is filled with multitudinous policy documents. This paper undertakes a systematic appraisal of the subsisting opportunities, pitfalls and dilemmas surrounding Nigeria's quest for alternative clean energy development. The data for this paper are generated from key informant interviews as well as formal policy documents and scholarly archival materials. The paper finds a huge gap between setting national energy transition targets and realizing same. It further finds that Nigeria is yet to begin its journey of energy transition from fossil fuels to renewable energy in real terms despite ambitious targets and projections. It links it to structural gaps, policy discordance, unconducive investment climate, questionable commitment of stakeholders to transit to renewable energy and inability to attract robust private investments. It recommends institutional overhaul to reposition the energy sector for real transition to green energy systems.
\end{abstract}

\section{Introduction}

Renewable and nonrenewable energy resources are abundant in Nigeria. Their abundance offers the country a wide latitude to harness and integrate them into its energy mix. On the wings of global deemphasis on fossil fuels due to their link with global warming and climate change, Nigeria began to develop policies to transit to alternative clean energy systems. Thus, Nigeria's policy domain is suffused with various types of policy documents, all of which contain strategies, frameworks, targets, projections and action plans on how to achieve green energy transition to meet national energy needs for the household, industrial and transportation sectors.

Notwithstanding Nigeria's endowment with renewable energy resources and a plethora of policy initiatives to harness these resources for energy generation, the country's energy sector still appears imperiled. The country's energy profile suggests that it is energy insecure. Energy insecurity in Nigeria has two sides. The first side is exemplified by the proportion of the population that has or does not have access to electricity. According to World Bank sources, only 54.4 percent of Nigerians had access to electricity as at 2017 (World Bank, n.d.). Both anecdotal evidence and responses from our key informants indicated that such factors as population growth, low-level of infrastructural investment, low power generation capacity and expansion in urban slums have actually reduced access to electricity. What this implies is that Nigeria is acutely deficient in terms of the percentage of the population that has access to electricity. A recent report put the number of Nigerians without access to electricity at 93 million (Ujamadu, 2018). The only condition for Nigeria to exit from the rank of countries with electricity access deficit is to expand its energy holdings. It is estimated that Nigeria would require to connect between 500,000 and 800,000 new households to the electricity grid on yearly basis between 2018 and 2030 to be able to achieve its targets of electricity access (Odin, 2018).

The second side of Nigeria's energy insecurity is the excessive power outages suffered by those that have electricity access. The outages diminish the kilowatt-hours available and therefore reduce the overall quality of access to electricity in the country. This has induced the prevalence of self-generation of power through small generators with attendant pressure on the environment and the economy (Nigerian Energy Support Programme, 2015; Osae-Brown and Olurounbi, 2019).

Nigeria's policy documents have various permutations and projections about how to expand the country's energy sector, especially through renewable energy sources. Beside the overall objective of

\footnotetext{
* Corresponding author. Department of Political Science and International Relations, Landmark University, Omu Aran, Kwara State, Nigeria.

E-mail addresses: nwozor.agaptus@1mu.edu.ng, agapman1@yahoo.co.uk (A. Nwozor).
} 
improving its energy profile, the major impetus to Nigeria's quest for green energy transition consists of meeting its international obligations, improving electricity access for its teeming population and driving economic growth. Nigeria has submitted various reports to the United Nations Framework Convention on Climate Change (UNFCCC), in line with its commitment to transiting to green energy. These reports include the First and Second National Communications in 2003 and 2014, the Intended Nationally Determined Contribution (INDC) in 2015, and the First Biennial Update Report (BUR1) in 2018. It also includes the development of a national Sustainable Energy for All Action Agenda (SE4ALL-AA) in 2016.

Green energy transition is a major avenue through which Nigeria's policy documents envisaged to expand electricity access. In this regard, there are ambitious targets for electricity access. The projections are that renewable energy would account for 30 percent of available electricity with access expanding from its 2016 level to 75 percent in 2020 and 90 percent in 2030 (Federal Republic of Nigeria, 2016a). In the economic sphere, the expansion of the energy sector is recognized as a catalyst for economic growth and national development through industrialization (Ministry of Budget and National Planning, 2017; Lin and Ankrah, 2019; Ogbonnaya et al., 2019). Thus, successive governments set diverse targets for the realization of green energy transition.

This paper undertakes the assessment of the interconnections between Nigeria's policy domain and its quest to enthrone green energy system as a means of meeting the country's energy needs. In particular, it evaluates two interrelated themes. One, whether policy formulation in the energy sector with specific reference to green energy transition has translated into the availability of alternative clean energy. And, two the extent to which various policy projections are on track to realizing the country's aspiration for green energy transition, including the expansion of access to electricity between now and 2030. Our evaluation is based on data generated from key informants and complemented with insights from relevant policy documents as well as other scholarly archival materials. The paper finds a disconnect between policy avowals in terms of targets and projections vis-à-vis the actualization of green energy transition. The key implication of this discordance is that Nigeria is already off-track in meeting any of its set targets as far as increasing the contributions of renewable energy in its energy mix is concerned.

Energy scholars have explored Nigeria's alternative green energy arena from diverse perspectives, employing theoretical, empirical and cross-disciplinary approaches. The result is that the energy arena has an impressive body of literature. However, the complexity of Nigeria's energy sector led scholars to focus preponderantly on the various dimensions of technical and economic feasibility of energy transition with limited attention paid to the policy arena (Ohunakin et al., 2014; Olatomiwa et al., 2016; Ogunmodimu and Okoroigwe, 2019; Adeniyi, 2019; Ohakwere-Eze et al., 2020; Ojo et al., 2020).

Thus, the corpus of literature on Nigeria's quest for alternative clean energy system has not primarily focused on the policy component in any systematic manner but rather in some sort of disparate and disconnected case study format (Ohimain, 2013a; Akuru and Okoro, 2014; Edomah et al., 2017; IRENA, 2018; Gungah et al., 2019). The novelty of this paper is the synthesization of the various policy documents on green energy transition in Nigeria in order to provide a more comprehensive account of the complex mix of factors that undermine the take-off of the transition. Thus, the paper achieves the aim of synthesizing and integrating the various documents and expert views to weave a single coherent and holistic description that provides a deep insight into the political-economic root causes of Nigeria's serial non-actualization of the targets for green energy transition.

Overall, the paper makes three interrelated contributions. First, although there is wide-ranging literature on renewable energy in Nigeria (variously reviewed in this paper), this is the first time that a holistic appraisal of representative policy documents on Nigeria's efforts towards energy transition to clean energy has been undertaken. This provides a veritable basis for applicable inferences to be drawn that are strategically important to developing the renewable energy sector. Thus, the paper is valuable in practical terms as it highlights areas where improvements might be most effective in facilitating Nigeria's transition to alternative clean energy. Second, the paper enriches the discourse on Nigeria's quest to mainstream renewable energy sources in its energy mix by identifying institutional and governance deficits. These deficits constitute the critical factors that have left Nigeria moving in circles with regard to transitioning to alternative clean energy systems. In other words, this paper introduces critical perspectives to complement the preponderance of the focus on technical and apolitical factors in extant literature. Finally, this paper brings together perceptions from several experts from several fields that provide a critically comprehensive insights into the impediments that underpin the disconnect between policies on renewable energy transition and their actualization.

The paper is organized into five sections. Section 1 covers the introduction. Section 2 provides a background that contextualizes the global quest for alternative clean energy development, which formed the basis for Nigeria's green energy transition drive. Section 3 discusses the methodology, which is anchored on key informant interviews and archival resources. Section 4 presents the findings with robust discussion, followed by conclusion and policy recommendations in section 5 .

\section{Contextualizing the global quest for alternative clean energy development}

One of the major areas that bears the brunt of contemporary civilization and its industrial achievements is the environment. Fossil fuels have been the drivers of industrialization since the industrial revolution. In the course of powering industrialization, fossil fuels have also created environmental crisis. The various phases in industrial evolution used different types of energy sources. These have ranged from various forms of biomasses to fossil fuels. The earliest epoch of industrialization transited from phytomass fuels to coal (Smil, 2008). Generally, technical knowledge and innovations often evolve and underpin the trajectory of modernization and civilization. In relation to energy systems and innovation, Chabrol (2016, p. 195) has pointed out that "the most important changes in energy systems depend indeed upon great innovations and technological developments ... [as well as the] society allowing their diffusion and integration into usage". The various types of fuels used in motorizing different civilizational revolutions constituted part of the energy systems. These fuel types played a key role in powering industrialization and spawning economic growth and social progress.

In the global energy sector, the innovations that led to a trajectory away from coal and transition to crude oil and gas were multifaceted. These innovations included the discovery and development of large oil and gas fields, competitive pricing of oil and gas relative to coal, and innovations in oil-and gas-related technologies, especially the development of small engines (Melsted and Pallua, 2018). Thus, the development of relevant technologies, both for oil exploitation and end usage represented the important innovations that brought the shift, which inexorably led to the abandonment of coal and embracement of oil and gas.

The profound impact of the oil-and-gas-induced technological change was such that "within a relatively short period of time in the mid twentieth century, coal-based energy solutions were largely replaced with hydrocarbon alternatives" (Melsted and Pallua, 2018, p. 396). In the same vein, coal lost its primacy and dominance as a primary energy source in Organization for Economic Co-operation and Development (OECD) countries. For instance, the dominance of coal as a primary energy source plummeted from 62 percent in 1940 to 23 percent in 1970 . For the same period under reference, oil and natural gas jumped from 26 percent to almost 70 percent (Melsted and Pallua, 2018).

The cumulative environmental impact of the use of fossil fuels to meet the expanding needs of modern industrialization is evident in the current global warming. Global warming constitutes the greatest 
environmental threat faced by the earth. Scientific evidence has established a direct link between global warming and greenhouse (GHG) emissions from human activities (IPCC, 2013; IPCC, 2019). The indictment of anthropogenic GHGs in global warming underpinned the pressure for collective action. Thus, the global quest for alternative clean energy sources to power contemporary industrialization was borne out of the overall desire to reduce anthropogenic GHG emissions.

The global effort to save the earth is built on multinational negotiations and collaboration due to the nature of the environment as a public good. Countries have internationally recognized boundaries and exercised control over environmental resources within their jurisdictions. However, there are limitations to such control, hence the designation of environmental resources as public goods (Uitto, 2016). What this implies is that states are generally incapable of limiting environmental problems to their territories or stopping them from encroaching into them. The cross-jurisdictional nature of environmental problems was captured by Sir Crispin Tickell's observation that "the atmosphere knows no boundaries and the winds carry no passports" (cited in Ennals, 1993). Thus, environmental problems are global in character as they are caused by many countries, affect all countries and can only be addressed by all countries acting as a collective and in unison (Uitto, 2016).

The starting point of the global commitment to save the earth could be periodized to 1992 when an Earth Summit was convened in Rio de Janeiro between 3rd and 14th June. It was at the event that the UNFCCC was signed by about 150 countries (United Nations, 1992). The number of countries in attendance was unprecedented and signified the international dimension of the problem. It also represented a global acknowledgement of the danger posed by climate change to the global environment and the preparedness of the international community for a collective action against it (Ennals, 1993).

Since the foundations laid by the UNFCCC, which entered into force in 1994, several conferences have been convened where several protocols and agreements were reached by countries, including Nigeria. The Paris Agreement, which is an important watershed in the international collaboration against climate change, came into force in 2016. The major goal of the Paris Agreement is the strengthening of global responses to climate change (Jacobs and Al-Azar, 2019) (Djalante, 2019). The Intergovernmental Panel on Climate Change (IPCC) has recently insisted that if the global community hopes to prevent global warming of $1.5^{\circ} \mathrm{C}$ or more above pre-industrial levels, then the $\mathrm{CO}_{2}$ emissions must be drastically reduced to net zero by 2050 (IPCC, 2019).

The panacea identified as capable of saving the environment is transitioning away from fossil fuels to a new energy system built on renewable resources. This is envisaged to facilitate the reduction of anthropogenic GHG emissions. Nigeria is among the countries that have set targets and developed policies for the development of its renewable energy sources. The overall objective of Nigeria's renewable energy program is to increase its percentage contribution in the country's energy mix. This ought not to be a problem considering Nigeria's endowment with abundant renewable energy resources. These renewables can effortlessly motorize the country's green energy transition. In view of the foregoing, Nigeria has developed diverse policy documents to underpin and drive its green energy transition.

The environmental problems associated with fossil fuels are at the root of Nigeria's quest to gradually expand the proportions of renewable energy in its energy mix. Within this context, the benefits of renewable energy have interrelated domestic and international dimensions. In the international sphere, it is envisaged to strengthen Nigeria's environmental diplomacy. Transition to green energy would help the country to meet its international obligations in the area of reducing GHG emissions. In the domestic arena, transition to renewable energy system would help to address the country's abysmal energy profile. Thus, fixing Nigeria's energy challenge would have multiplier effects, in terms of providing an enabling investment climate with attendant positive impact on economic growth and development. This thinking informed the plethora of pro-green energy policies that predominate Nigeria's policy domain
(Federal Republic of Nigeria, 2016a). Table 1 below presents a synthesis of the major policy initiatives adopted at various times by successive administrations to drive Nigeria's quest for green energy transition.

Nigeria's quest for national development, as articulated in its various development visions recognized the imperative of an energy roadmap for their actualization. Nigeria has developed a motley of policies, action plans and implementation strategies to signpost its desire to expand and diversify its energy holdings. However, developing these energy polices have not posed as much a challenge as implementing their contents. Since 1999, successive administrations have made the pursuit of energy sufficiency their cardinal goal.

\section{Methodology}

Nigeria is endowed with all the major types of renewable energy resources. It has also evolved various policies to drive the utilization and conversion of these resources into energy sources. Paradoxically, the country is still energy-insecure. Over the years, Nigeria has evolved several policies to achieve green energy transition. The overarching goal of Nigeria's aspiration to transit to green energy system is to expand its energy holdings to meet the country's energy needs. Flowing from this goal are such multiplier effects as the reduction of the contribution of fossil fuels to Nigeria's energy generation, the scaling down of environmental pollution and economic benefits like the creation of green jobs.

In investigating the extent to which Nigeria's overarching goal of transiting to green energy system has been realized, this paper generated data from key informant interviews, policy documents and scholarly archival materials. A total of ten key informants were chosen through purposive sampling technique. The choice of the key informants was based on their established knowledge of Nigeria's energy sector through their affiliations, research interests and/or previous commentaries (see Appendix 1).

The issue of adequate number of interviews to be conducted in a qualitative research has been an ongoing debate (Dworkin, 2012; Hagaman and Wutich, 2016). While quantitative research has clear-cut mathematical rules for determining sample sizes based on such factors as reference population, type of analysis, confidence level required, and sampling techniques among others, qualitative research lacks a precise formula for determining the number of interviews to be conducted (Dworkin, 2012; Galvin, 2015). However, there is an emerging agreement that there is no magical number of interviews that should constitute an established rule of thumb.

There are two key considerations with regard to the number of interviews in qualitative research, namely whether the number of interviews is deemed adequate based on the specific context of the research (criterion of adequacy) and whether a saturation point has been reached (criterion of saturation or informational redundancy) (Vasileiou et al., 2018). A saturation point is reached when there are repetitive comments by subsequent informants or "the point at which the data collection process no longer offers any new or relevant data" (Dworkin, 2012, p. 1319). Thus, several scholars have provided diverse insights into the number of respondents/interviews that could lead to the attainment of the saturation point. Although outlier ranges of 1-260 have been proposed by some scholars (Baker and Edwards, 2012), generally the range revolves around 6 to 30 interviews (Hennink et al., 2016; Vasileiou et al., 2018; Guest et al., 2020). The ultimate choice of the number of interviews depends on the scope of the research, the phenomena under investigation, the homogeneity or heterogeneity of target audience and the level of expertise of the key informants (Guest et al., 2006, 2020; Baker and Edwards, 2012; Hagaman and Wutich, 2016).

On the basis of the foregoing and in line with the focus of this study, which is the systematic appraisal of Nigeria's policy thrust on alternative clean energy, ten key informants were adopted. The choice of the number of key informants (KIs) was predicated on the critical 
Table 1

A synthesis of key policy initiatives for green energy transition.

\begin{tabular}{|c|c|}
\hline $\begin{array}{l}\mathrm{S} / \\
\mathrm{N}\end{array}$ & $\begin{array}{l}\text { Policy document and } \\
\text { background information }\end{array}$ \\
\hline 1 & $\begin{array}{l}\text { National Energy } \\
\text { Policy (NEP) (2003) } \\
\text { (Reviewed in 2013, } \\
\text { and recently in } \\
\text { 2018). } \\
\text { - An initial Energy } \\
\text { Policy Guideline was } \\
\text { drafted in } 1984 \text { by the } \\
\text { Federal Ministry of } \\
\text { Science and } \\
\text { Technology. This was } \\
\text { reviewed and } \\
\text { expanded in } 1993 \text { and } \\
\text { 1996. In } 2003 \text {, the } \\
\text { Energy Commission of } \\
\text { Nigeria (ECN) } \\
\text { midwifed the first } \\
\text { National Energy } \\
\text { Policy for Nigeria } \\
\text { (NEP). The policy was } \\
\text { approved in } 2003 \text { and } \\
\text { later launched by the } \\
\text { President on June } 20 \text {, } \\
\text { 2005. The NEP was } \\
\text { later reviewed in } 2013 \\
\text { and recently in } 2018 .\end{array}$ \\
\hline 2 & $\begin{array}{l}\text { Renewable Energy } \\
\text { Master Plan (REMP), } \\
\text { (2005), (2012). } \\
\text { - The REMP document } \\
\text { was prepared under } \\
\text { the auspices of the } \\
\text { ECN and the United } \\
\text { Nations Development } \\
\text { Programme (UNDP). } \\
\text { The REMP articulated } \\
\text { a roadmap to facilitate } \\
\text { the expansion of the } \\
\text { role of RE in achieving } \\
\text { sustainable national } \\
\text { development. }\end{array}$ \\
\hline
\end{tabular}

The REMP articulated a national roadmap with vision, targets and comprehensive framework to ensure the exploitation and accelerated development of RE resources to address key development challenges facing Nigeria.
- Renewable Electricity
Policy Guidelines (REPG) (2006).

\begin{tabular}{|c|c|}
\hline objective & expected deliverables \\
\hline $\begin{array}{l}\text { NEP represented a } \\
\text { coordinated and } \\
\text { coherent blueprint for } \\
\text { sustainable energy } \\
\text { solution, in terms of } \\
\text { energy development, } \\
\text { supply and } \\
\text { utilization. }\end{array}$ & $\begin{array}{l}\text { - The policy covered } \\
\text { the energy sector, } \\
\text { including renewable } \\
\text { energy (RE), energy } \\
\text { efficiency and rural } \\
\text { electrification. } \\
\text { - Targeted a } \\
\text { widespread } \\
\text { production and } \\
\text { installation of RE } \\
\text { systems and } \\
\text { mainstream them } \\
\text { into the national } \\
\text { energy mix } \\
\text { - Targeted to make } \\
\text { electricity available } \\
\text { to } 75 \% \text { of the } \\
\text { population by the } \\
\text { year } 2020 \text {. } \\
\text { - Targeted to increase } \\
\text { power generation to } \\
40 \text { GW by } 2020 \text {. }\end{array}$ \\
\hline
\end{tabular}

The REMP had several targets and projections. - It projected electricity supply from conventional and renewable sources thus: short term (2007) - 7,000 MW; medium (2015) - 14,000 MW; and long term (2025) 29,000 MW. This projection was anchored on ECN's High Growth Scenario for energy demand.

- The projections about the contributions of RE sources were $56 \mathrm{MW}$, 701 MW and 3,060 MW in 2007, 2015 and 2025 respectively.

- The REMP projected that 300,000 , 500,000 and $1,000,000$ units of improved woodstoves would be distributed in 2007 , 2015 and 2025 respectively.

- It also estimated that $40,000,400,000$ and 4,000,000 solar home systems and $1,500,50,000$ and 150,000 solar cookers would be distributed in 2007, 2015 and 2025 respectively.

The REPG served as a The REPG projected the common framework - Expansion of to facilitate the Nigeria's capacity in
Table 1 (continued)

\begin{tabular}{|c|c|c|c|}
\hline $\begin{array}{l}\mathrm{S} / \\
\mathrm{N}\end{array}$ & $\begin{array}{l}\text { Policy document and } \\
\text { background information }\end{array}$ & $\begin{array}{l}\text { Overall policy } \\
\text { objective }\end{array}$ & $\begin{array}{l}\text { Key policy thrust and } \\
\text { expected deliverables }\end{array}$ \\
\hline & $\begin{array}{l}\text { The REPG drew from } \\
\text { previous documents, } \\
\text { especially the } \\
\text { National Electric } \\
\text { Power Policy of 2001, } \\
\text { NEP (2003), the REMP } \\
\text { (2005), the draft Rural } \\
\text { Electrification Policy } \\
\text { (which was later } \\
\text { approved in 2009), } \\
\text { and the National } \\
\text { Economic } \\
\text { Empowerment and } \\
\text { Development Strategy } \\
\text { (NEEDS) among } \\
\text { others }\end{array}$ & $\begin{array}{l}\text { meeting of national } \\
\text { electricity needs } \\
\text { through the } \\
\text { integration of } \\
\text { renewables into the } \\
\text { electricity mix. }\end{array}$ & $\begin{array}{l}\text { electricity generation } \\
\text { to meet set goals for } \\
\text { national economic } \\
\text { and social } \\
\text { development. } \\
\text { - Diversification of } \\
\text { electricity supply by } \\
\text { integrating } \\
\text { renewable energy } \\
\text { sources. } \\
\text { - Expansion of the } \\
\text { market for renewable } \\
\text { electricity to a } \\
\text { minimum of } 5 \% \text { of } \\
\text { total electricity } \\
\text { generating capacity } \\
\text { by } 2016 . \\
\text { - Provision of support } \\
\text { to ensure electricity } \\
\text { access for areas not } \\
\text { connected to the } \\
\text { national electricity } \\
\text { grid, especially } \\
\text { through the } \\
\text { construction of } \\
\text { independent } \\
\text { renewable electricity } \\
\text { systems. }\end{array}$ \\
\hline 4 & $\begin{array}{l}\text { Renewable Electricity } \\
\text { Action Programme } \\
\text { (REAP) (2006). } \\
\text { - The REAP was } \\
\text { developed by the } \\
\text { Federal Ministry of } \\
\text { Power and Steel in } \\
2006 \text { as a roadmap for } \\
\text { the implementation of } \\
\text { the REPG }\end{array}$ & $\begin{array}{l}\text { The REAP recognized } \\
\text { RE as possessing } \\
\text { unique key to scale up } \\
\text { access to electricity } \\
\text { services and thus help } \\
\text { to meet national } \\
\text { targets. }\end{array}$ & $\begin{array}{l}\text { The REAP provided a } \\
\text { 10-year framework to } \\
\text { implement the REPG } \\
\text { and targeted the } \\
\text { achievement of the } \\
\text { following projects } \\
\text { between } 2007 \text { and } \\
\text { 2016: } \\
\text { - Generation of a } \\
\text { cumulative } \\
\text { renewable energy of } \\
735 \text { MW by } 2016 . \\
\text { - } 2 \text { million new } \\
\text { connections. } \\
\text { - } 1 \text { million solar home } \\
\text { systems. } \\
\text { - } 2000 \text { Rural } \\
\text { electrification of } \\
\text { Schools via solar. } \\
\text { - } 2000 \text { Rural } \\
\text { electrification of } \\
\text { community health } \\
\text { centers and clinics } \\
\text { via solar } \\
\text { - } 10,000 \text { highway } \\
\text { streetlights powered } \\
\text { by solar. } \\
\text { - Bagasse cogeneration } \\
\text { electricity project } \\
\text { (105 MW) } \\
\text { Wind power } \\
\text { electricity project } \\
\text { (100 MW). }\end{array}$ \\
\hline 5 & $\begin{array}{l}\text { National Biofuel } \\
\text { Policy and Incentives } \\
\text { (2007). } \\
\text { Based on the directive } \\
\text { of the government in } \\
\text { August 2005, the } \\
\text { NNPC developed a } \\
\text { biofuel policy to drive } \\
\text { domestic fuel ethanol } \\
\text { industry. }\end{array}$ & $\begin{array}{l}\text { The biofuel policy } \\
\text { was designed to } \\
\text { develop an } \\
\text { automotive biomass } \\
\text { program for the } \\
\text { country. }\end{array}$ & $\begin{array}{l}\text { - The key expectations } \\
\text { of the policy included } \\
\text { enhancing the } \\
\text { economic potentials } \\
\text { of the agricultural } \\
\text { sector by integrating } \\
\text { it with the } \\
\text { downstream } \\
\text { petroleum sector; } \\
\text { and creating a viable } \\
\text { fuel ethanol industry } \\
\text { for national } \\
\text { development, } \\
\text { (continued on next page) }\end{array}$ \\
\hline
\end{tabular}


Table 1 (continued)

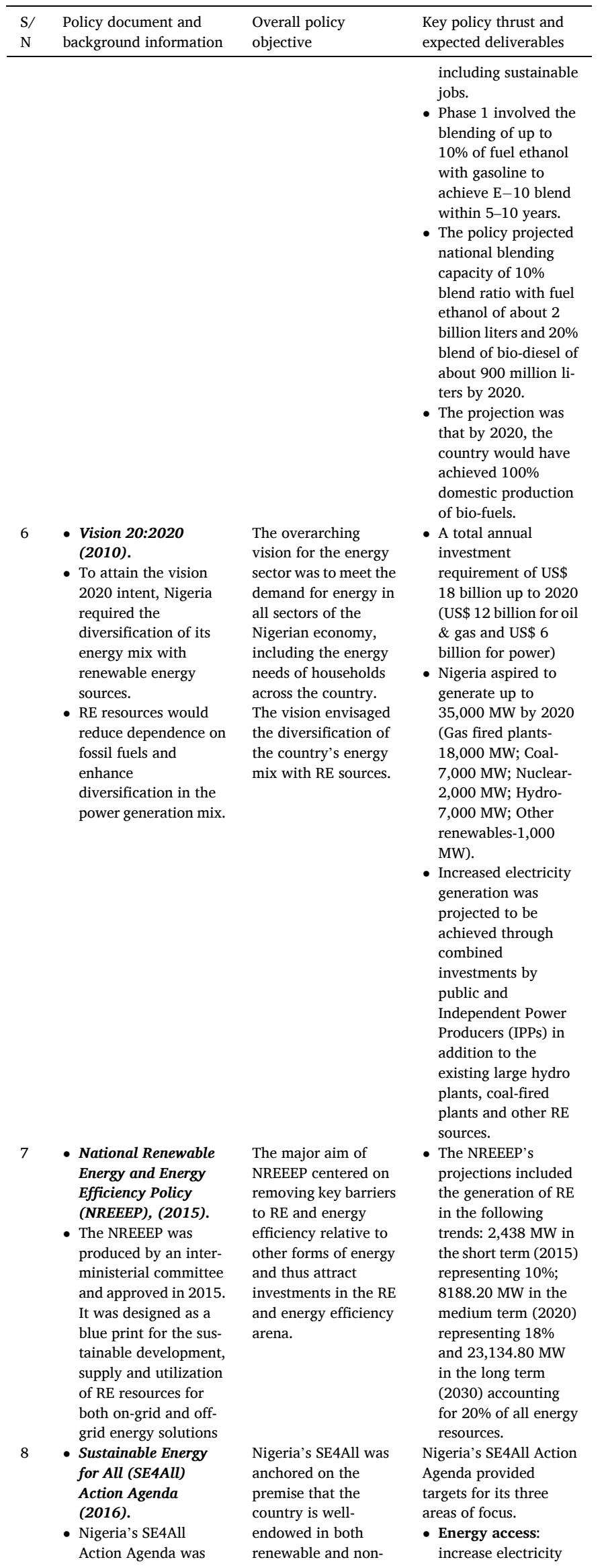

Table 1 (continued)

\begin{tabular}{|c|c|c|c|}
\hline $\begin{array}{l}\mathrm{S} / \\
\mathrm{N}\end{array}$ & $\begin{array}{l}\text { Policy document and } \\
\text { background information }\end{array}$ & $\begin{array}{l}\text { Overall policy } \\
\text { objective }\end{array}$ & $\begin{array}{l}\text { Key policy thrust and } \\
\text { expected deliverables }\end{array}$ \\
\hline & $\begin{array}{l}\text { developed with inputs } \\
\text { from all stakeholders } \\
\text { across relevant } \\
\text { platforms. } \\
\text { It was also developed } \\
\text { in tandem with the } \\
\text { objectives of SE4All } \\
\text { Global Agenda 2012, } \\
\text { focusing on three } \\
\text { areas, namely energy } \\
\text { access, energy } \\
\text { efficiency, and } \\
\text { renewable energy. }\end{array}$ & $\begin{array}{l}\text { renewable energies } \\
\text { that could be } \\
\text { harnessed to address } \\
\text { existing shortfalls in } \\
\text { energy and power } \\
\text { access. }\end{array}$ & $\begin{array}{l}\text { access from the } \\
\text { current aggregate } \\
\text { level of } 40 \% \text { - to } 75 \% \\
\text { by } 2020 \text {. } \\
\text { - Replace firewood for } \\
\text { household cooking } \\
\text { with improved } \\
\text { cookstove } \\
\text { technology by } 50 \% \\
\text { in } 2020 \text { and } 80 \% \text { by } \\
2030 . \\
\text { Leverage nuclear } \\
\text { energy to contribute } \\
\text { about } 2.5 \% \text { and } 4 \% \\
\text { to available } \\
\text { electricity mix by } \\
2025 \text { and } 2030 \\
\text { respectively. } \\
\text { Energy Efficiency: } \\
\text { introduce efficient } \\
\text { energy technologies } \\
\text { such that energy } \\
\text { efficiency would } \\
\text { increase by at least } \\
20 \% \text { by } 2020 \text { and } \\
50 \% \text { by } 2030 \text { when } \\
\text { compared with the } \\
2015 \text { level. } \\
\text { - Introduce } \\
\text { compulsory energy } \\
\text { audits for all high- } \\
\text { energy consuming } \\
\text { sectors and efficient } \\
\text { lighting, such that by } \\
2020 \text { and } 2030,40 \% \\
\text { and } 100 \% \text { of house- } \\
\text { electricity mix would } \\
\text { holds would have } 30 \% \text { by } \\
\text { keyed into it. } \\
\text { Renewable energy: } \\
\text { expansion of all } \\
\text { renewable energy } \\
\text { sources, such that } \\
\text { the contributions to } \\
\text { be }\end{array}$ \\
\hline 9 & $\begin{array}{l}\text { National Renewable } \\
\text { Energy Action Plan } \\
\text { (NREAP), } \\
\text { 2015-2030 (2016). } \\
\text { - The NREAP was } \\
\text { developed in response } \\
\text { to the directive in } \\
\text { NREEEP. } \\
\text { - The Action Plan } \\
\text { benefitted from inputs } \\
\text { from over twenty } \\
\text { Federal Ministries, } \\
\text { Departments and } \\
\text { Agencies and other } \\
\text { stakeholders. } \\
\text { The Action Plan } \\
\text { integrated aspects of } \\
\text { Electricity Vision 30- } \\
\text { 30-30 }\end{array}$ & $\begin{array}{l}\text { NREEEP projected to } \\
\text { increase the share of } \\
\text { on-grid renewable } \\
\text { energy (RE) in the } \\
\text { total electricity } \\
\text { supply from } 1.3 \% \text { in } \\
2015 \text { to } 16 \% \text { by } 2030 \text {. } \\
\text { However, in NREAP } \\
2016 \text {, this target was } \\
\text { reviewed to } 30 \% \text { of } \\
\text { renewable energy by } \\
2030 \text {. }\end{array}$ & $\begin{array}{l}\text { The key targets of } \\
\text { NREAP included: } \\
\text { - Increasing the grid- } \\
\text { connected RE to: } \\
5,325 \mathrm{MW} \text { in } 2020 \\
\text { and } 13,800 \mathrm{MW} \text { by } \\
2030 \\
\text { - Expanding the share } \\
\text { of population using } \\
\text { improved cookstove } \\
\text { to: } 40 \% \text { in } 2020 \text { and } \\
59 \% \text { by } 2030 \text {. } \\
\text { - Improving biofuels } \\
\text { such that ethanol as } \\
\text { share of gasoline } \\
\text { consumption would } \\
\text { be } 33.18 \% \text { in } 2020 \\
\text { and } 57.34 \% \text { by } 2030 \text {. } \\
\text { - Expanding biodiesel } \\
\text { as share of diesel and } \\
\text { fuel oil consumption } \\
\text { to: } 6.2 \% \text { in } 2020 \text { and } \\
17.45 \% \text { by } 2030 \text {. }\end{array}$ \\
\hline
\end{tabular}

Sources: Extracted from various policy documents 
consideration of satisfying the conditions of adequacy and saturation. The ten KIs possessed a high level of knowledge and expertise as well as provided overarching and encompassing deep insights in relation to the topic of inquiry that additional inclusion of respondents was considered superfluous.

The participation of the key informants was based on voluntary acceptance. They granted verbal permission for the interview to be conducted. They were fully aware of their freedom to discontinue with the interview at any point in time without any obligation to offer justification for their decision. Based on our prior agreement, the identities of the interviewees have been shielded to protect them from any form of backlashes. Semi-structured set of questions served as the instrument with which data were generated from the key informants (see Appendix 2). The data were complemented with secondary data gathered from policy documents and archival materials. All the data were qualitatively analyzed through the instrumentality of logical inductive method.

\section{Findings and discussion}

The paper is anchored on the broad question of whether the various policies enacted by successive Nigerian governments have catalyzed green energy transition. Put differently, the key informants were broadly interviewed on whether there is any decipherable connection between the multitudinous policies in Nigeria's energy domain and the realization of the overarching goal of transiting to a green energy system. Semistructured set of interview questions constituted the data-gathering instrument. Semi-structured interview format provided room for the key informants to elaborate on their views as might be necessary. Additionally, the diversity of the policies and the seeming complexity of Nigeria's energy sector made semi-structured format quite appropriate. Our thematic analysis identified and validated three major themes that captured all the data from the interviews. The three themes included: disconnect between abundance and utilization of renewable energy resources, the pitfalls of green energy transition, and serial policy uncertainties that have spawned dilemmas. Table 2 below contains the synthesis of the answers from our key informant interviews and emerging themes generated therefrom.

\subsection{The opportunities and the disconnect: between renewable resource abundance and utilization challenges}

The key informants agreed that Nigeria's pursuit of energy sufficiency is also organically linked with its desire to be the powerhouse of industrialization in Africa. The rebasing of Nigeria's gross domestic product (GDP) in 2014 led to its becoming the largest economy in Africa ahead of South Africa (Masetti, 2014). Nigeria's status as the largest economy in Africa intensified the pressure on its government to take advantage of this reclassification to attract foreign direct investment to fast-track development in the country (Masetti, 2014; Willem Te Velde et al., 2016; Cook, 2019). The basis for the pressure was anchored on the sentiment that notwithstanding the challenging operational environment in Nigeria, the country's economy has become too important an asset for businesses to ignore (Cook, 2019).

The seeming perennial challenge faced by Nigeria and its energy policymakers is how to leverage the boundless opportunities in its renewable energy endowments to achieve two interrelated purposes. One, to resolve the gap in its energy needs, and two, to ensure improved resilience and sustainability of its energy sector. Nigeria is extremely rich in renewable energy resources, including hydro, sun, wind, tidal and others, which could easily be included in its energy mix to meet and even surpass the country's energy needs (Shaaban and Petinrin, 2014; Akuru et al., 2017).

The key informants identified the factors militating against the development of Nigeria's renewable energy sector to include the country's overly dependence on fossil fuels, the absence of sustained
Table 2

Overview of findings.

\begin{tabular}{|c|c|c|}
\hline Focus of research question & $\begin{array}{l}\text { Summary of key } \\
\text { informants' views }\end{array}$ & Emerging theme \\
\hline $\begin{array}{l}\text { Evaluation of the policy } \\
\text { domain vis-à-vis the } \\
\text { adequacy of policies for } \\
\text { green energy transition }\end{array}$ & $\begin{array}{l}\text { Countless policies aimed at } \\
\text { shepherding Nigeria to } \\
\text { alternative clean energy } \\
\text { abound in the country's } \\
\text { policy arena } \\
\text { There is confusion about } \\
\text { operable policies and } \\
\text { coordinating institutional } \\
\text { framework } \\
\text { The various policy } \\
\text { documents contain } \\
\text { adequate agenda in terms } \\
\text { of conceptualizing clear } \\
\text { goals. However, there is no } \\
\text { clear-cut workable } \\
\text { implementation strategy. } \\
\text { There is no consistent and } \\
\text { clearly discernible } \\
\text { institutional driver for the } \\
\text { alternative clean energy } \\
\text { transition agenda. } \\
\text { There is a disconnect in } \\
\text { terms of hierarchizing RE } \\
\text { sources. Similarly, there is } \\
\text { no policy designating the } \\
\text { order of choices in the } \\
\text { development of renewable } \\
\text { energy sources. }\end{array}$ & Policy disconnect \\
\hline $\begin{array}{l}\text { Linkage between green } \\
\text { energy transition } \\
\text { policies and green } \\
\text { energy development } \\
\text { and government's } \\
\text { commitment to walking } \\
\text { the talk in terms of } \\
\text { transiting to green } \\
\text { energy }\end{array}$ & $\begin{array}{l}\text { Nigeria has not leveraged } \\
\text { the boundless opportunities } \\
\text { in its renewable energy } \\
\text { endowments to resolve the } \\
\text { gap in its energy needs. } \\
\text { The focus of successive } \\
\text { Nigerian governments has } \\
\text { been on developing RE } \\
\text { policies without any form } \\
\text { of appraisal of earlier } \\
\text { policies. } \\
\text { Nigeria's policy initiatives } \\
\text { have remained idealistic } \\
\text { and prescriptive, thus } \\
\text { lacking the critical element } \\
\text { of implementation. }\end{array}$ & Policy uncertainty \\
\hline $\begin{array}{l}\text { The nature of challenges } \\
\text { with Nigeria's quest for } \\
\text { alternative green } \\
\text { energy }\end{array}$ & $\begin{array}{l}\text { Unwieldy number of RE } \\
\text { policies is unhealthy for the } \\
\text { sector as it makes it difficult } \\
\text { to forge a united policy } \\
\text { bloc. } \\
\text { The absence of a holistic } \\
\text { policy framework } \\
\text { underpins the limited } \\
\text { progress in the RE sector } \\
\text { despite the trillions of naira } \\
\text { spent to revitalize the } \\
\text { energy sector since } 1999 \\
\text { Nigeria's RE sector has not } \\
\text { been able to attract serious } \\
\text { private investment due } \\
\text { mainly to the uncertainty } \\
\text { that characterizes the } \\
\text { sector. } \\
\text { The inability to attract the } \\
\text { private sector means huge } \\
\text { financing gap. Thus, lack of } \\
\text { capital inflow necessary to } \\
\text { move the sector to the next } \\
\text { level has contributed in } \\
\text { stymieing the realization of } \\
\text { green energy transition in } \\
\text { the country. }\end{array}$ & $\begin{array}{l}\text { Stagnancy in green } \\
\text { energy transition }\end{array}$ \\
\hline $\begin{array}{l}\text { The possibility of } \\
\text { transiting to clean }\end{array}$ & $\begin{array}{l}\text { The politics of energy } \\
\text { transitions, which is }\end{array}$ & \\
\hline
\end{tabular}


Table 2 (continued)

\begin{tabular}{|c|c|c|}
\hline Focus of research question & $\begin{array}{l}\text { Summary of key } \\
\text { informants' views }\end{array}$ & Emerging theme \\
\hline $\begin{array}{l}\text { alternative energy and } \\
\text { the evident and likely } \\
\text { impediments to its } \\
\text { actualization both in } \\
\text { the short and long runs } \\
\text { Oil subsidy and its price } \\
\text { distortions act as } \\
\text { disincentive to transition } \\
\text { to green energy. }\end{array}$ & $\begin{array}{l}\text { characterized by vested } \\
\text { political interests, has had } \\
\text { negative impacts on the } \\
\text { trajectory of alternative } \\
\text { clean energy agenda. } \\
\text { There is a clash between } \\
\text { the business interests of } \\
\text { political elites and the } \\
\text { aspirations of the state to } \\
\text { enthrone an alternative } \\
\text { clean energy. This has } \\
\text { placed the entire green } \\
\text { energy transition program } \\
\text { at a disadvantage with } \\
\text { negative impact on its } \\
\text { actualization. }\end{array}$ & $\begin{array}{l}\text { Need to refocus on } \\
\text { clear implementation } \\
\text { strategies }\end{array}$ \\
\hline $\begin{array}{l}\text { There is an evident } \\
\text { unattractiveness of the RE } \\
\text { sector due to the } \\
\text { mismatch between the } \\
\text { cost of investment and } \\
\text { accruable benefits. } \\
\text { Economic unattractiveness } \\
\text { of the RE sector due to } \\
\text { policy uncertainty and } \\
\text { inconsistency constitutes } \\
\text { the key impediment to } \\
\text { robust private sector } \\
\text { participation. }\end{array}$ & & \\
\hline
\end{tabular}

investment in the renewable energy subsector and lack of technical capacity to midwife sustainable energy transitions. Thus, the core development challenge faced by Nigeria has been how to find a sustainable way to meet the growing energy needs of its increasing population and the industrial sector.

Nigeria's National Energy Policy (NEP) of 2003, which is its overall energy policy document, made provisions for the exploitation and utilization of all available energy resources to meet the country's energy needs, including the development of cleaner coal technology and the deployment of appropriate technology to harvest gas that was hitherto routinely flared (Energy Commission of Nigeria, 2014).

The various energy policy documents outlined roadmaps and strategies to actualize Nigeria's energy transition. Nigeria's Vision 20:2020, which has been abandoned, recognized energy sufficiency as an important ingredient in the country's aspiration to be in the league of the top 20 economies in the world by 2020 (Federal Republic of Nigeria, 2009). The main thrust of the Vision centered on increasing Nigeria's GDP to about US\$ 900 billion and its per capita income to about US\$ 4000 (Energy Commission of Nigeria, 2014).

The realization of this type of aspirational vision would definitely require a quantum leap in infrastructural development, especially in the energy sector. In this direction, the Vision targeted an ambitious expansion in capacity utilization in both electricity generation and domestic refining. The projections of the Vision included a target of increasing Nigeria's electric power generation from $4000 \mathrm{MW}$ in 2007 to 35,000 MW by 2020 and the nameplate refining capacity of its refineries from 445,000 barrels a day (b/d) to 750,000 b/d in 2015 and 1,500,000 b/d in 2020 (Energy Commission of Nigeria, 2014). The key informants collectively agreed that these projections were unrealistic considering the absence of clear-cut strategies for implementation. Fig. 1 shows conventional/non-renewable resources in Nigeria. Currently, the Nigerian government's focus is on crude oil and natural gas development.

The key informants noted that since 2010, there have been ambitious adjustments to energy targets, further making them unachievable. For instance, the Power Sector Roadmap of 2010 revised the attainable target in the electricity sector to $40,000 \mathrm{MW}$. The realization of the

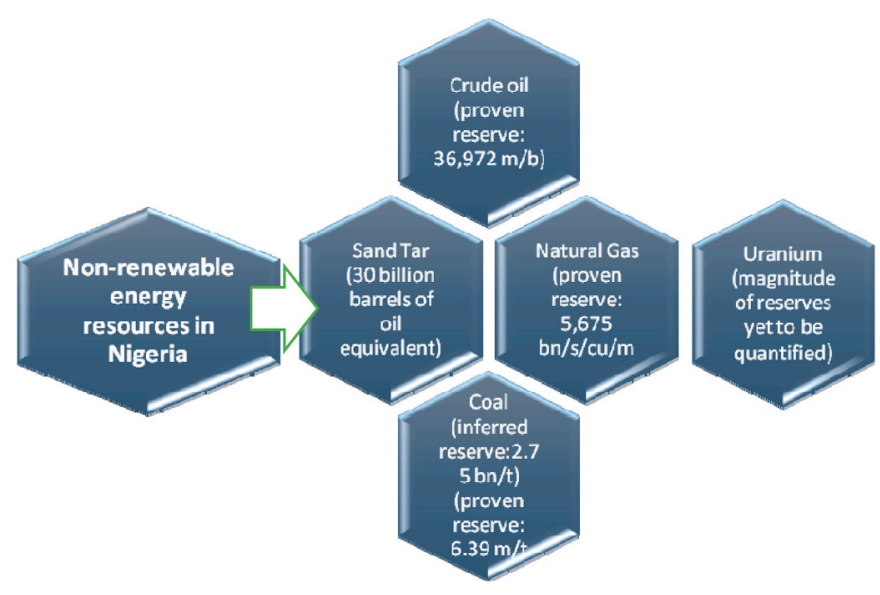

Fig. 1. Conventional energy resources in Nigeria (Sources: Energy Commission of Nigeria, 2014; OPEC, 2019).

target was predicated on yearly investments of at least US $\$ 3.5$ billion in the power generating capacity of the country for the ten years following the vision year (Federal Republic of Nigeria, 2010). The Roadmap recognized that in order for the targets to be realized, corresponding large investments would also need to be made along the chains of the electricity sector through the incentivization of the private sector to partner with government (Federal Republic of Nigeria, 2010).

More current policy documents like National Renewable Energy and Energy Efficiency Policy (NREEEP), Sustainable Energy for All Action Agenda (SE4ALL-AA), National Renewable Energy Action Plan have revised the targets to $32,000 \mathrm{MW}$ with 30 percent contributions envisioned from renewable energy sources. Nigeria's extant economic policy document, the Economic Recovery and Growth Plan (ERGP), a Medium Term Plan for 2017-2020, clearly recognizes the indispensability of energy sufficiency in the pursuit of economic growth. To this end, the ERGP has committed to optimizing "the delivery of at least $10 \mathrm{GW}$ of operational capacity by 2020 and to improve the energy mix including through greater use of renewable energy" (Ministry of Budget and National Planning, 2017, p. 31).

\subsection{From prospects to stagnation: the pitfalls of green energy transition}

The various policy thrusts for the revitalization of Nigeria's energy sector painted a picture of bright prospects of achieving energy security through the development of the renewable energy subsector. The Renewable Energy Master Plan (REMP) and National Biofuel Policy and Incentives constitute the fundamental policy initiatives that articulated the progressive mainstreaming of renewable energy into Nigeria's energy mix. The role envisaged for renewable energy in Nigeria's energy mix goes beyond the electricity subsector. Its role is economy-wide. The projection was that dedicated implementation would result in renewable energy-driven economy (ECN \& UNDP, 2005).

For Nigeria to achieve a green economy, however, REMP envisioned the exploitation of renewable energy resources in such quantities that could translate to competitive prices. Competitive pricing is the key to promoting equitable and sustainable growth. Thus, several scenarios were created, namely the Reference Scenario (RS), the High Growth Scenario (HGS), and the Low Growth Scenario (LGS). The REMP envisioned that under the HGS, the country would generate $7000 \mathrm{MW}$, $14000 \mathrm{MW}$ and $29000 \mathrm{MW}$ for the short, medium and long-terms respectively (ECN \& UNDP, 2005).

Nigeria's motley of policies contains a range of implementable measures, plans and pathways to facilitate the actualization of the country's renewable energy targets by 2030 . Apart from the electricity sector, targets for renewable energy application in other sectors of the economy have also been set. For instance, renewable energy is 
envisioned to be deployed to domestic uses. It is estimated that over 75 percent of the Nigerian population uses traditional biomass for cooking (Federal Republic of Nigeria, 2016a). The target is to reverse this figure by modernizing cookstove technology and making them available to the populace. Thus, the projection is that the share of the population using improved cookstove would move from 0.24 percent in 2010 to 40 percent in 2020 and then 59 percent in 2030 (Federal Republic of Nigeria, 2016b).

There is no doubt that Nigeria has made tremendous efforts in harnessing its renewable energy resources judging by its policy thrusts. For instance, Nigeria submitted the First and Second National Communications in 2003 and 2014 respectively. It also submitted the Intended Nationally Determined Contribution (INDC) in 2015, the First Biennial Update Report (BUR1) in 2018 and developed a national Sustainable Energy for All Action Agenda (SE4ALL-AA) in 2016. Additionally, the country has made efforts to implement some policies targeted at clean energy development such as the Clean Development Mechanism (CDM) projects, as well as projects financed by the Adaptation Fund (Federal Ministry of Environment, 2015). However, the problem is the disconnect between projections and realization.

For instance, with regard to the CDM, the emphasis has been basically on the oil sector rather than the renewable energy sector. By the projection of Nigeria's Electricity Vision 30-30-30, renewable energy should constitute 30 percent of electricity generation in the country by 2030. In the same vein, households were projected to transit to the use of modern cooking fuels such as electricity, liquefied petroleum gas (LPG), kerosene, biogas and solar cookers for their domestic needs. From the baseline estimate of 10 percent household access to modern cooking fuels as at 2016, it was projected that by 2020 and 2030, the household access would expand to 50 and 80 percent respectively (Federal Republic of Nigeria, 2016a; Federal Republic of Nigeria, 2016b). The 2030 projection of access to cooking fuels also indicated that the remaining 20 percent would be taken care of through improved wood cookstoves as well as efficient charcoal production (Federal Republic of Nigeria, 2016a).

The major pitfall in Nigeria's quest for massive development of its renewable energy sector is the serial non-realization of set targets. There is a serious disconnect between official projections and targets as contained in the various energy policy documents and the situation on ground. It would appear as if the Nigerian energy sector is frozen in time and, therefore, impervious to necessary impetus for its transformation. Nigeria's Roadmap for Power Sector Reform was a program designed to provide guidelines on how to restructure the electricity subsector and achieve stable electricity in the country. During its launch in 2010, former President Goodluck Jonathan identified the absence of a longterm power development strategy, under-exploitation of the country's abundant energy endowments and lack of adequate implementation of reforms as the key factors affecting the delivery of reliable electricity services (Adeoye, 2010; Tattersall, 2010; Modern Ghana, 2010). The key informants agreed that Nigeria has not been able to overcome these constraints.

KI- 6 contended that the thinking among policy-makers concerning how to address Nigeria's energy crisis could, arguably, be described as narrow and simplistic. For instance, it would appear that the focus is on pumping funds into the electricity subsector simply to build more power stations without a holistic strategy. KI-7 argued further that no specific policy thrust recognized the imperative of expanding institutional capacity, strengthening research and development (R\&D), and designing and deploying appropriate technologies, including backup technologies to achieve set targets.

The absence of a holistic framework constitutes part of the explanations for the limited progress in the energy sector despite the trillions of naira spent to revitalize it since 1999. For instance, while Obasanjo's administration spent an estimated US\$16 billion, the Umaru Yar'Adua and Goodluck Jonathan administrations reportedly pumped N1.183 trillion and N1.817 trillion into the sector respectively (Gyamfi, 2018;
Adanikin, 2019). Since 2015, it is estimated that the Muhammadu Buhari administration has spent over N1.5 trillion in the electricity subsector (Adanikin, 2019). Interestingly, despite these huge capital injections into the electricity subsector, Nigeria is still entrapped in electricity poverty.

The key informants described the progress in the electricity subsector as uninspiring as it is still far below projections. However, there has been modest improvement since 1999. Prior to 1999, the country's total installed electricity generation capacity was about $5580 \mathrm{MW}$ with power generation in the neighborhood of 1724.9 MW and 1859.8 MW (Central Bank of Nigeria, 2004). The current total installed capacity of 12,522 MW depicts a massive improvement. A disaggregation of the installed capacity shows the dominance of thermal power source. While thermal power source accounts for between 75 and 85 percent of electric power generation, hydropower contributes between 15 and 25 percent, depending on both the state of gas supply and the hydro plants.

The current average generation of electricity shows that Nigeria is still a very long way off the track in achieving set targets in the subsector. Fig. 2 below shows available generation capacity and average monthly generation between January and September 2019. From the figure, it could be deduced that in the period under reference, the highest available generation capacity was $6,862 \mathrm{MW}$ and the highest average monthly generation was 4,209 MW both of which are a far cry from the projections and targets for 2020.

The major attraction of renewable energy, apart from its cleanness and environmental-friendliness, is its adaptability to meet varied energy needs, including electricity access to rural communities (Federal Ministry of Power and Steel, 2016) (Ezirim et al., 2016); energy needs of households and the transportation sector (Federal Republic of Nigeria, 2016a). For instance, under the auspices of Nigeria's Biofuel Policy and Incentives, the national projection was to blend 10 percent by volume of fuel-ethanol in gasoline and 20 percent by volume of biodiesel in automotive gas oil (diesel) for use in the transportation sector (Ohimain, 2013a). The purpose of the blending is to enhance the quality of petroleum products with a view to reducing tailpipe emissions and ozone pollution. The timeline for the full development of sufficient capacity and capability to birth a vibrant biofuels subsector was between 5 and 10 years. In other words, based on the projections and targets of the biofuels policy, Nigeria would have developed full production capacity of its biofuels by 2017. Apart from environmental considerations, a vibrant biofuel sector would raise additional tax revenue and create green jobs, which would empower farmers and rural communities (Ohimain, 2013a), (Ohimain, 2013b).

Based on Nigeria's energy projections, the country should by 2020 be generating 5,325 MW from the various renewable energy sources (Federal Republic of Nigeria, 2016b). With the translation of the projection into reality, the renewable energy sources should be supplying 20,031 GWh, which would constitute 38 percent of the country's

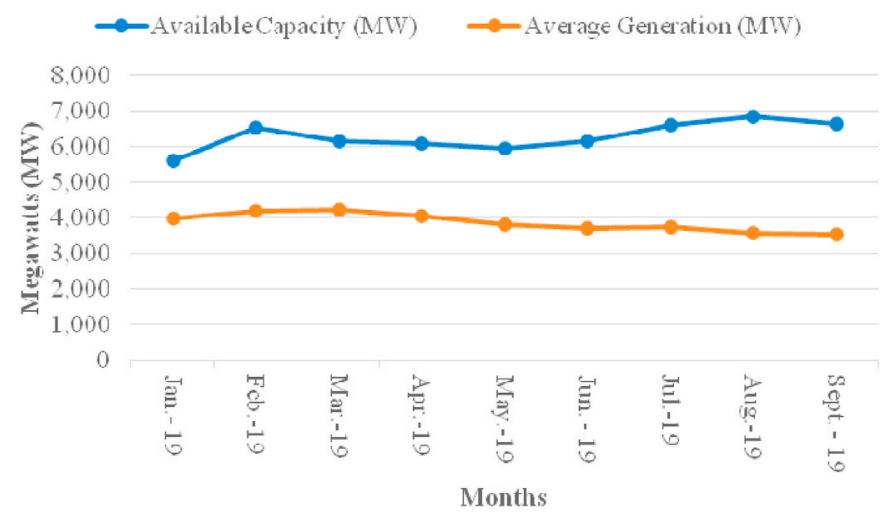

Fig. 2. Available capacity and average monthly generation for Q1-Q3 of 2019 (Source: NERC, 2019). 
electricity mix. So far, this is a mirage that is far from actualization. While Fig. 3 captures the projected contributions of renewables and fossil fuels to the electricity mix, Fig. 4 shows the projected contributions of the various renewable energy sources to the total renewable energy holdings of the country. Nigeria is currently off-track in their realization.

\subsection{Serial policy uncertainties: unmasking the multiple dilemmas}

One of the major requirements for a successful clean energy transition is the availability of technical knowledge to drive it. This is so because energy transitions are not happenstance as they involve complex processes of innovation and structural changes (Chabrol, 2016). These changes often involve long-term visioning that spans technology development, knowledge generation on the compatibility of new and old technologies for continued provision of services, and the wider societal impacts of such new technologies (Osunmuyiwa et al., 2018). KI-10 noted that the low power density of renewable energy sources in terms of their capacity to generate large or substantial quantities of electric power in comparison to nonrenewable energy sources underscores the criticality of developing technical capacity to pursue energy transitions. Nigeria has not developed the critical technical knowledge base. It has also not optimized renewable energy technologies or developed the attendant human capacity to drive the renewable energy transition programs in any coordinated manner (Ogbonnaya et al., 2019).

A related dilemma is how to match the cost of renewable energy sources to the accruable benefits. The current state of renewable energy development is unattractive because of associated high operational costs. The high operational costs are linked to the uncertainties often triggered by the general unpredictability of wind and sunlight (Lin and Ankrah, 2019). For instance, a 2016 estimate indicated that it would cost about US\$517 to generate 1 MW-hour of electricity from onshore wind and between US\$625 and \$764 to generate same from solar sources (Lin and Ankrah, 2019). In contrast, it would cost far less to generate same from coal or gas-fired plants, which is in the range of \$80-\$110 (Lin and Ankrah, 2019).

Successive Nigerian governments have consistently recognized that progress in the energy sector would require a robust private sector involvement. However, this has not happened as envisaged. The key informants agreed that the inability of the government to attract serious private investors to the energy sector is yet another pitfall that has stymied the realization of green energy transition in the country. KI-4 pointed out that Nigeria's history of policy inconsistencies and summersaults was the most singular factor that discouraged robust private sector participation and investment. KI-8 buttressed that policy inconsistency constituted a minus for the country because it eroded the

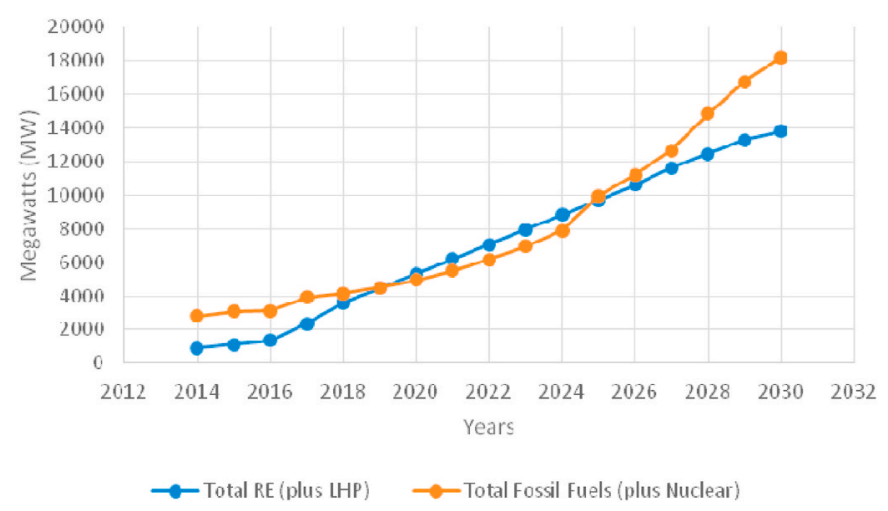

Fig. 3. Projections of the contributions of renewable energy sources and fossil fuels to the electricity generation mix. (Sources: Federal Republic of Nigeria 2016a; Federal Republic of Nigeria 2016b).

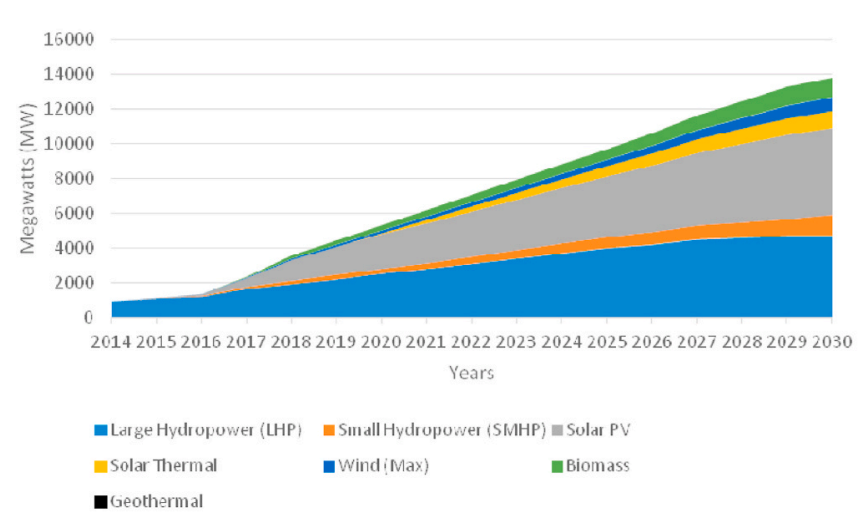

Fig. 4. Projected contributions of the various renewable energy sources (Source: Federal Republic of Nigeria 2016b).

confidence of potential investors. KI-2 further elaborated that despite the approval of feed-in tariff (FIT) regulation in 2015 by the Nigerian government, nothing could be seen on the ground in terms of private participation and investment.

The FIT regulation, which entered into force in February 2016, was designed to incentivize and stimulate investment interest in the renewable energy subsector. It guaranteed a stable price for renewable energy production for a fixed duration and stable return on investment, both which were aimed at reducing the risks associated with these projects (Federal Republic of Nigeria, 2016b). However, there is still lack of massive private sector involvement. The position of our key informants was that both the economic consideration of the attractiveness of FIT and concerns about policy inconsistency constituted key impediments to robust private sector participation in the renewable energy subsector.

Thus, to be able to encourage private investors already operating in the electricity chain and attract prospective investors to commit the type of funds needed by the sector to develop the renewable energy subsector, there must be cast-iron guarantees on the protection of such investments. In other words, there must be important policy reforms that would clearly pave a more favorable investment path for renewable energy technology as well as reassure prospective investors that such policies and regulatory frameworks would not be subject to arbitrary changes.

Another key source of pitfall and associated dilemma, which has created a huge gap between projections and non-accomplishment, is the politics of energy transitions. As Osunmuyiwa et al. (2018) have pointed out, while certain actors might be pertinent drivers of transitions, they could be limited when faced with vested political interests that represent alternative ideas. In Nigeria, the triad of corrupt bureaucrats and politicians, a clique of vested business interests, and the chronically incompetent and inefficient state-run utilities have combined to resist genuine energy transitions.

The politician-tycoon-bureaucrat complex (see Fig. 5) has undermined progress in Nigeria's quest for energy system transition. This has most clearly played out in the lingering reform of the petroleum sector as

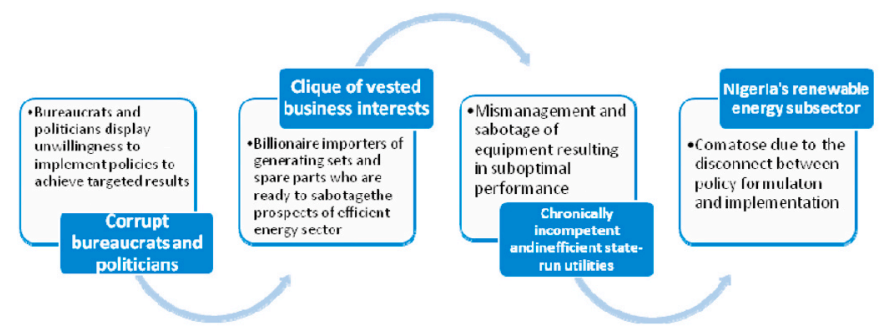

Fig. 5. The triad complex in Nigeria's energy sector. 
well as in the area of oil subsidy (Nwozor et al., 2020). Nigeria has been subsidizing refined petroleum products since its four refineries began to demonstrate increasing incapacity to meet domestic demands. Available data showed that oil subsidy has been gulping a sizable chunk of Nigeria's annual budgets. For instance, while N780 billion was spent for oil subsidy in 2019, data indicated that between 2006 and 2018, the total sum of N10 trillion was spent by the Nigerian government to subsidize refined petroleum products (Sun, 2020).

The whole idea of oil subsidy is to make refined petroleum products available and affordable in the domestic market through government's intervention by picking a portion of the actual cost of importing these products (Osunmuyiwa et al., 2018). The unintended offshoot of subsidies was that the domestic prices of refined petroleum products became the cheapest in West Africa, paving the way for massive smuggling of the products (Nwozor and Oshewolo, 2020). Our key informants noted that apart from the black market profiteers, fuel subsidies also created elite politico-economic parasites. The resulting conflict of interests undermined Nigeria's quest to transit to renewable energy systems. In effect, Nigeria's projections for renewable energy deployment have had to contend with its political system, which is dominated by widespread rentierism and strong networks of actors who benefit therefrom (Osunmuyiwa et al., 2018).

Oil subsidy has had two important elements that undermine green energy system transition. The first is price distortion, which makes refined petroleum products artificially cheaper than renewable energy, thus discouraging the pursuit of alternative energy development (Osunmuyiwa et al., 2018). The second is the network of patronage created by oil subsidy payouts resulting in massive corruption (Akov, 2015; Abdul-Baki et al., 2019). The strong preference of political elites for the continuation of oil subsidy provides the incentive for the sabotage of any policy whose focus is to develop a competing renewable energy subsector. A cross-section of our key informants opined that a related area of sabotage is orchestrated by tycoon-importers of portable power generating sets. The electricity crisis in Nigeria has created a thriving multi-billion dollar business niche for small power generating sets. It is estimated that between 22 and 60 million generating sets are in use in Nigeria (Nigerian Energy Support Programme, 2015; Otene et al., 2016; Osae-Brown and Olurounbi, 2019). It logically follows that any resolution of the energy crisis would result in the demise of this sector. Our key informants believed that this triggered subtle alliances that contributed in undermining the realization of green energy projections and targets.

As at the end of 2019 and early 2020, the renewable energy targets were basically far from being actualized. The various renewable energy sources, which were projected to come on stream to make contributions to the target of $5,325 \mathrm{MW}$ by 2020 have not done so. According to the Nigerian Electricity Regulatory Commission's quarterly report for the third quarter of 2019, the country's available average generation capacity was 6709 MW while the highest peak daily generation was 5093 MW translating to 7,984,685 MWh (NERC, 2019). The bottom-line is that by the third quarter of 2019, Nigeria was yet to generate up to 50 percent of its installed electricity capacity, an indication of a wide berth in its energy projections. Interestingly, renewable energy sources did not feature in the electricity generation mix for this period except the age-old large hydropower plants (LHPs). The actual performance of the electricity sector vis-à-vis its total available capacity meant that about 46.09 percent of this capacity was redundant (NERC, 2019). The poor performance was blamed on technical and operational constraints spanning "inadequate gas supply, water management [challenges] at the hydropower stations, transmission constraints, and limited distribution networks and commercially induced low load off-take by DisCos" (NERC, 2019, p. 24). Interestingly, these same factors had featured in previous policy and energy review documents as being the key constraints and impediments to improving electricity generation and distribution.

\section{Conclusion and policy implications}

Despite the avalanche of policies to harness Nigeria's abundant renewable energy resources and thus actualize its alternative clean energy goals, the country is completely off-track in this regard. The composition of the sources of Nigeria's electricity generation for the third quarter of 2019 showed the continued dominance of thermal plants as they contributed 74.63 percent to the national electricity mix while the large hydropower plants accounted for the remaining 25.37 percent. For the period under reference, the power generation efficiency rate was only 53.91 percent with 46.09 percent being redundant (NERC, 2019). There was no record that any of the renewable energy sources, such as wind, small hydro, solar PV and biomass, which had been projected to contribute to the country's energy mix, actually did or likely to do so in the foreseeable future.

The broad policy implication established in this study is the incongruence of policymaking and policy implementation as well as actualization. While policies provide a veritable basis for setting targets and making projections, the engagement of the policies through actionable plans and strategies are indispensable in realizing set targets. A specific policy implication of the non-actualization of Nigeria's green energy transition is the persistence of energy deficits in the country. The energy deficits may likely worsen, given the deterioration of the thermal plants due to age and pressure of overuse. Green energy transition is indispensable if Nigeria intends to meet its domestic and international obligations with regard to energy sufficiency and clean environment. Evidence from this study highlights the imperative of improving policy coordination and spawning institutional reforms in order to attract private sector investment to boost the renewable energy subsector.

A major attraction of renewable energy technologies (RETs) is their decentralized and modular nature, which could facilitate easy adoption as well as deployment to meet diverse energy demands, including in the rural areas. The modular nature of most RETs, low investment requirements and the possibility of utilizing locally available resources make them a choice for serious consideration (Karekezi and Kithyoma, 2003). Additionally, RETs could provide opportunities for developing local expertise that might facilitate technology transfer necessary for a sustainable clean energy transition.

In addition to the adoption of RETs, the government must package its green energy program to be driven by the private sector in all ramifications. In order to build confidence among prospective private investors and attract their investment funds, energy reforms must have cast-iron guarantees that they would be implemented. There is also need for policy coordination to ensure a single agenda. This would facilitate the reorganization of the energy sector, enthrone a conducive operational environment and eliminate the uncertainty and ambiguity that have undermined robust pursuit of the green energy agenda.

\section{Declaration of competing interest}

The authors declare that they have no known competing financial interests or personal relationships that could have appeared to influence the work reported in this paper. 


\section{Appendix 1. Breakdown/composition of key informants}

\begin{tabular}{ll}
\hline Key Informant ID & Occupational/professional affiliation \\
\hline KI-1 & Mid-level and Senior- level officials of Nigeria's power ministry \\
KI-2 & \\
KI-3 & \\
KI-4 & \\
KI-5 & Academics/Researchers with core research interest in the energy sector from public and private universities in Nigeria \\
KI-6 & \\
KI-7 & \\
KI-8 & Energy analysts \\
KI-9 & Consultant/independent electrical engineer \\
KI-10 & \\
\hline
\end{tabular}

\section{Appendix 2. Interview questions with room for elaboration}

\begin{tabular}{ll}
\hline $\mathrm{S} / \mathrm{N}$ & Lead Questions \\
\hline 1 & How would you evaluate the policy domain of Nigeria's energy sector? \\
2 & Do you think there is adequate policy framework for green energy transition in Nigeria? \\
3 & Is there any discernible connection between green energy transition policies and green energy development in Nigeria? \\
4 & Do you think that the government is committed to walking the talk in terms of transiting to green energy? \\
5 & Do you think there are challenges with Nigeria's quest for alternative green energy? \\
6 & Do you think that Nigeria can transit to clean alternative energy? \\
7 & Are there evident and likely impediments to the realization of green energy transition both in the short and long runs? \\
\hline
\end{tabular}

\section{References}

Abdul-Baki, Z., Uthman, A.B., Kasum, A.S., 2019. The role of accounting and accountants in the oil subsidy corruption scandal in Nigeria. Crit. Perspect. Account. https://doi. org/10.1016/j.cpa.2019.102128.

Adanikin, O., 2019. Jonathan, Buhari Spent N1.164 Trn on Power in 8 Years [WWW Document]. Dly. Trust. URL. https://www.dailytrust.com.ng/jonathan-buhari-spent -n1-164-trn-on-power-in-8-years.html. accessed 4.20.20.

Adeniyi, F., 2019. Overcoming the Market Constraints to On-Grid Renewable Energy Investments in Nigeria [WWW Document]. Oxford Inst. Energy Stud. Pap. EL 37 URL. https://www.oxfordenergy.org/wpcms/wp-content/uploads/2019/11/Overco ming-the-Market-Constraints-to-On-Grid-Renewable-Energy-Investments-in-NigeriaEL37.pdf. accessed 4.20.20.

Adeoye, Y., 2010. Power sector reforms: Jonathan, the power president. Vanguard [WWW Document]. https://www.vanguardngr.com/2010/09/power-sector-reform s-jonathan-the-power-president/. (Accessed 20 December 2019).

Akov, E.T., 2015. Fuel subsidy corruption and the illusions of economic reconstruction in Nigeria. Acad. J. Interdiscip. Stud. 4, 395-406. https://doi.org/10.5901/mjss.2015. v4n1p395.

Akuru, U.B., Okoro, O.I., 2014. Renewable energy investment in Nigeria: a review of the renewable energy master plan. J. Energy South Afr. 25, 67-73.

Akuru, U.B., Onukwube, I.E., Okoro, O.I., Obe, E.S., 2017. Towards 100\% renewable energy in Nigeria. Renew. Sustain. Energy Rev. 71, 943-953. https://doi.org/ 10.1016/j.rser.2016.12.123.

Baker, S.E., Edwards, R., 2012. How many qualitative interviews is enough? Expert voices and early career reflections on sampling and cases in qualitative research [WWW Document] Natl. Centr. Res. Methods Rev. Paper. URL. http://eprints.ncrm. ac.uk/2273/4/how many interviews.pdf.

Central Bank of Nigeria, 2004. Statistical Bulletin, vol. 15. Central Bank of Nigeria, Abuja.

Chabrol, M., 2016. Re-examining historical energy transitions and urban systems in Europe. Energy Res. Soc. Sci. 13, 194-201. https://doi.org/10.1016/j. erss.2015.12.017.

Cook, M., 2019. This Country Recently Became Africa's Largest Economy. Now It's Too Big for Businesses to Ignore [WWW Document]. Brink News. URL. https://www. brinknews.com/this-country-recently-became-africas-largest-economy-now-its-toobig-for-businesses-to-ignore/. accessed 4.30.20.

Djalante, R., 2019. Key assessments from the IPCC special report on global warming of $1.5{ }^{\circ} \mathrm{C}$ and the implications for the Sendai framework for disaster risk reduction. Prog. Disaster Sci. 1, 100001. https://doi.org/10.1016/j.pdisas.2019.100001.

Dworkin, S.L., 2012. Sample size policy for qualitative studies using in-depth interviews. Arch. Sex. Behav. 41, 1319-1320. https://doi.org/10.1007/s10508-012-0016-6.

ECN \& UNDP, 2005. Renewable energy master plan [WWW Document]. URL. http ://iceednigeria.org/backup/workspace/uploads/nov.-2005.pdf. accessed 3.25.20.

Edomah, N., Foulds, C., Jones, A., 2017. Policy making and energy infrastructure change: a Nigerian case study of energy governance in the electricity sector. Energy Pol. 102, 476-485. https://doi.org/10.1016/j.enpol.2016.12.053.

Energy Commission of Nigeria, 2014. Energy implications of vision 20:2020 and beyond [WWW Document]. URL. http://www.energy.gov.ng/releases/Energy Requirement for Vision 2020 III Revised Ed.pdf. accessed 4.17.20.

Ennals, Lord, 1993. The significance of the Rio earth summit. Med. War 9, 191-198. https://doi.org/10.1080/07488009308409103.
Ezirim, G., Eke, O., Onuoha, F., 2016. The political economy of Nigeria's power secto reforms : challenges and prospects , 2005-2015. Mediterr. J. Soc. Sci. 7, 443-453. https://doi.org/10.5901/mjss.2016.v7n4p.

Federal Ministry of Environment, 2015. Nigeria's intended nationally determined contribution [WWW Document]. URL. https://www4.unfccc. int/sites/ndcstaging/PublishedDocuments/Nigeria First/Approved Nigeria\%27s INDC 271115.pdf. accessed 3.20.20.

Federal Ministry of Power and Steel, 2016. Renewable electricity policy guidelines [WWW Document]. URL. http://iceednigeria.org/backup/workspace/uploads/dec -2006.pdf. accessed 4.20.20.

Federal Republic of Nigeria, 2016a. Sustainable energy for all action agenda (SE4ALL AA) [WWW Document]. URL. https://www.se4all-africa.org/fileadmin/uploads /se4all/Documents/Country_AAs/NIGERIA_SE4ALL_ACTION_AGENDA_FINAL.pdf. accessed 4.30.20.

Federal Republic of Nigeria, 2016b. National renewable energy action plans (NREAP) (2015-2030) [WWW Document]. URL. https://www.se4all-africa.org/fileadmin/u ploads/se4all/Documents/Country_PANER/Nigeria_National_Renewable_Energ Y_Action_Plans_.pdf. accessed 3.15.20.

Federal Republic of Nigeria, 2010. Roadmap for power sector reform [WWW Document]. URL. https://www.proshareng.com/admin/upload/report/Roadmap for Power Se ctor Reform Full Version.pdf. accessed 4.30.20.

Federal Republic of Nigeria, 2009. Report of the Vision 2020 National Technical Working Group on Energy Sector [WWW Document]. URL. http://www.npc.gov. ng/vault/NTWG Final Report/culture,tourism \& national re-oreintation ntwg report. pdf\%5Cn. http://www.npc.gov.ng/vault/files/small and medium enterprises ntwg report.pdf\%5Cn. http://www.npc.gov.ng/vault/NTWG Final Report/financial sector ntw. accessed 4.20.20.

Galvin, R., 2015. How many interviews are enough? Do qualitative interviews in building energy consumption research produce reliable knowledge? J. Build. Eng. 1, 2-12. https://doi.org/10.1016/j.jobe.2014.12.001.

Guest, G., Bunce, A., Johnson, L., 2006. How many interviews are enough? An experiment with data saturation and variability. Field Methods 18, 59-82. https:// doi.org/10.1177/1525822x05279903.

Guest, G., Namey, E., Chen, M., 2020. A simple method to assess and report thematic saturation in qualitative research. PloS One 15, e0232076. https://doi.org/10.1371/ journal.pone.0232076.

Gungah, A., Emodi, N.V., Dioha, M.O., 2019. Improving Nigeria's renewable energy policy design: a case study approach. Energy Pol. 130, 89-100. https://doi.org/ 10.1016/j.enpol.2019.03.059.

Gyamfi, C.C., 2018. Obasanjo Releases EFCC Report on Alleged \$16b Power Project Expenditure [WWW Document]. Guardian. URL. https://guardian.ng/news/obasan jo-releases-efcc-report-on-alleged-16b-power-project-expenditure/. accessed 4.22.20.

Hagaman, A.K., Wutich, A., 2016. How many interviews are enough to identify metathemes in multisited and cross-cultural research? Another perspective on Guest, Bunce, and Johnson's (2006) landmark study. Field Methods 29, 23-41. https://doi. org/10.1177/1525822x16640447.

Hennink, M.M., Kaiser, B.N., Marconi, V.C., 2016. Code saturation versus meaning saturation: how many interviews are enough? Qual. Health Res. 27, 591-608.

IPCC, 2019. Global warming of $1.5^{\circ} \mathrm{C}$. An IPCC special report on the impacts of global warming of $1.5^{\circ} \mathrm{C}$ above pre-industrial levels and related global greenhouse gas emission pathways, in the context of strengthening the global response to the threat 
of climate change [WWW Document]. URL. https://www.ipcc.ch/site/assets/uploa ds/sites/2/2019/06/SR15 Full Report High Res.pdf.

IPCC, 2013. In: Stocker, T.F., Qin, D., Plattner, G.-K., Tignor, M.M.B., Allen, S.K., Boschung, J., Nauels, A., Xia, Y., Bex, V., Midgley, P.M. (Eds.), Climate Change 2013 the Physical Science Basis. Working Group I Contribution to the Fifth Assessment Report of the Intergovernmental Panel on Climate Change. Cambridge University Press, Cambridge, p. 1535pp.

IRENA, 2018. Policies and Regulations for Renewable Energy Mini-Grids. International Renewable Fnergy Agency, Abu Dhabi, UAF.

Jacobs, H., Al-Azar, R., 2019. Dare to Understand and Measure (DaTUM): A Literature Review of Monitoring and Evaluation (M\&E) Framework. Food and Agriculture Organization of the United Nations, Rome.

Karekezi, S., Kithyoma, W., 2003. Renewable Energy Development, the Workshop for African Energy Experts on Operationalizing the NEPAD Energy Initiative, 2- 4 June, 2003 at Novotel, Dakar, Senegal.

Lin, B., Ankrah, I., 2019. On Nigeria's renewable energy program: examining the effectiveness, substitution potential, and the impact on national output. Energy 167, 1181-1193. https://doi.org/10.1016/j.energy.2018.11.031.

Masetti, O., 2014. Nigeria: The no. 1 African economy [WWW Document]. http://www. fullertreacymoney.com/system/data/files/PDFs/2014/April/15th/Nigeria_The No_1_African_economy.pdf. (Accessed 4 July 2020).

Melsted, O., Pallua, I., 2018. The historical transition from coal to hydrocarbons: previous explanations and the need for an integrative perspective. Can. J. Hist. 53, 395-422. https://doi.org/10.3138/cjh.ach.53.3.03.

Ministry of Budget, National, Planning, 2017. Nigeria economic recovery and growth plan,2017-2020 [WWW Document]. URL. https://nigeriaembassygermany.org/ mosaic/ M userfiles/Economic-Recovery-Growth-Plan-2017-2020.pdf. accessed 4.30.20.

Modern Ghana, 2010. President Jonathan's full speech on roadmap of power sector reform [WWW Document]. URL. https://www.modernghana.com/news/293498/p resident-jonathans-full-speech-on-roadmap-of.html (accessed 4.30.20).

NERC, 2019. NERC quarterly report, third quarter, 2019 [WWW Document]. URL. https://nerc.gov.ng/index.php/library/documents/func-download/769/ch k,5b660cdb8c4c06a7888f0734cc532d45/no html,1/. accessed 4.30.20.

Nigerian Energy Support Programme, 2015. The Nigerian energy sector: an overview with a special emphasis on renewable energy, energy efficiency and rural electrification [WWW Document]. URL. https://www.giz.de/en/downloads /giz2015-en-nigerian-energy-sector.pdf. accessed 3.20.20.

Nwozor, A., Olanrewaju, J.S., Adedire, S.A., Lawal, E.E., 2020. Reform in a limbo: the politics and politicization of reforms in Nigeria's petroleum sector. Int. J. Energy Econ. Pol. 10, 184-193. https://doi.org/10.32479/ijeep.9085.

Nwozor, A., Oshewolo, S., 2020. Nigeria's border closure drama: the critical questions. Round Table 109, 90-91. https://doi.org/10.1080/00358533.2020.1715106.

Odin, G., 2018. Nigeria ranked 2nd largest electricity access deficit in world as $80 \mathrm{~m}$ homes live without power. Businessamlive [WWW Document]. https://www.busin essamlive.com/nigeria-ranked-2nd-largest-electricity-access-deficit-in-world-as80m-homes-live-without-power/. (Accessed 22 April 2020).

Ogbonnaya, C., Abeykoon, C., Damo, U.M., Turan, A., 2019. The current and emerging renewable energy technologies for power generation in Nigeria: a review. Therm. Sci. Eng. Prog. 13 https://doi.org/10.1016/j.tsep.2019.100390.

Ogunmodimu, O., Okoroigwe, E.C., 2019. Solar thermal electricity in Nigeria: prospects and challenges. Energy Pol. 128, 440-448. https://doi.org/10.1016/j. enpol.2019.01.013.

Ohakwere-Eze, M.C., Udo, A.A., Nosike, C.V., Alhassan, A., Adamu, M.K., 2020 Appraisal of the wind potential as an alternative source of energy in Kashere, Gombe State, Nigeria. FUDMA J. Sci. 4, 446-452. https://doi.org/10.33003/fjs-2020-0403411.
Ohimain, E.I., 2013a. Can the Nigerian biofuel policy and incentives (2007) transform Nigeria into a biofuel economy? Energy Pol. 54, 352-359. https://doi.org/10.1016/ j.enpol.2012.11.051.

Ohimain, E.I., 2013b. A review of the Nigerian biofuel policy and incentives (2007) Renew. Sustain. Energy Rev. 22, 246-256. https://doi.org/10.1016/j. rser.2013.01.037.

Ohunakin, O.S., Adaramola, M.S., Oyewola, O.M., Fagbenle, R.O., 2014. Solar energy applications and development in Nigeria: drivers and barriers. Renew. Sustain. Energy Rev. 32, 294-301. https://doi.org/10.1016/j.rser.2014.01.014.

Ojo, A.A., Awogbemi, O., Ojo, A.O., 2020. An overview of the exploitation of renewable energy resources in Nigeria, South Africa, and the United Kingdom. Int. J. Renew. Energy Resour. 10, 843-860.

Olatomiwa, L., Mekhilef, S., Ohunakin, O.S., 2016. Hybrid renewable power supply for rural health clinics (RHC) in six geo-political zones of Nigeria. Sustain. Energy Technol. Assessments 13, 1-12. https://doi.org/10.1016/j.seta.2015.11.001.

OPEC, 2019. Annual Statistical Bulletin. Organization of the Petroleum Exporting Countries, Vienna.

Osae-Brown, A., Olurounbi, R., 2019. Nigeria Runs on Generators and Nine Hours of Power a Day [WWW Document]. Bloomberg. URL. https://www.bloomberg.com/ne ws/articles/2019-09-23/nigeria-runs-on-generators-and-nine-hours-of-power-a-day. accessed 3.28.20

Osunmuyiwa, O., Biermann, F., Kalfagianni, A., 2018. Applying the multi-level perspective on socio-technical transitions to rentier states: the case of renewable energy transitions in Nigeria. J. Environ. Pol. Plann. 20, 143-156. https://doi.org/ 10.1080/1523908X.2017.1343134.

Otene, I., Murray, P., Enongene, K., 2016. The potential reduction of carbon dioxide (CO2) emissions from gas flaring in Nigeria's oil and gas industry through alternative productive use. Environments 3, 1-20. https://doi.org/10.3390/ environments 3040031.

Shaaban, M., Petinrin, J.O., 2014. Renewable energy potentials in Nigeria: meeting rural energy needs. Renew. Sustain. Energy Rev. 29, 72-84. https://doi.org/10.1016/j. rser.2013.08.078.

Smil, V., 2008. Energy in Nature and Society: General Energetics of Complex Systems. The MIT Press, Cambridge. https://doi.org/10.1017/CBO9781107415324.004.

Sun, 2020. Fuel subsidy removal : matters arising [WWW Document]. URL. https://www .sunnewsonline.com/fuel-subsidy-removal-matters-arising/. accessed 4.30.20.

Tattersall, N., 2010. Nigeria leader unveils plan to end power shortages. Reuters [WWW Document]. https://af.reuters.com/article/topNews/idAFJOE67P0IQ20100826. (Accessed 30 April 2020).

Uitto, J.I., 2016. Evaluating the environment as a global public good. Evaluation 22, 108-115. https://doi.org/10.1177/1356389015623135.

Ujamadu, V., 2018. 93m Nigerians Have No Access to Electricity — power for All [WWW Document]. Vanguard. URL. https://www.vanguardngr.com/2018/10/93m-nigeri ans-have-no-access-to-electricity-power-for-all/. accessed 7.5.20.

United Nations, 1992. United nations framework convention on climate change [WWW Document]. URL. https://unfccc.int/resource/ccsites/zimbab/conven/text/fulltext. htm. accessed 3.20.20.

Vasileiou, K., Barnett, J., Thorpe, S., Young, T., 2018. Characterising and justifying sample size sufficiency in interview-based studies: systematic analysis of qualitative health research over a 15-year period. BMC Med. Res. Methodol. 18, 148.

Willem Te Velde, D., Booth, D., Leipziger, D., Uneze, E., 2016. Supporting economic transformation in Nigeria [WWW Document]. https://set.odi.org/wp-content/uploa ds/2016/05/SET-Nigeria-Paper-May-2016.pdf. (Accessed 4 July 2020).

World Bank. World development indicators. n.d [WWW Document]. URL. http://wdi. worldbank.org/table/WV.3. accessed 7.5.20. 